\title{
PENGEMBANGAN MEDIA TRAVEL GAME \\ UNTUK PEMBELAJARAN PERKALIAN DAN PEMBAGIAN \\ BILANGAN PECAHAN MATEMATIKA SD KELAS V
}

\section{THE DEVELOPING TRAVEL GAME MEDIA FOR MULTIPLICATION AND DIVISION OF FRACTION MATHEMATICS LEARNING IN GRADE V ELEMANTARY SCHOOL}

\author{
Delia Indrawati, Siti Partini Suardiman \\ PPs UNY ,Universitas Negeri Yogyakarta \\ indrawati.delia11@gmail.com, -
}

\begin{abstract}
Abstrak
Penelitian ini bertujuan untuk mengembangkan media travel game sehingga diketahui: (1) kelayakan media travel game untuk pembelajaran matematika kelas V SD materi perkalian dan pembagian bilangan pecahan, (2) keefektivan penerapan media travel game untuk pembelajaran matematika kelas V SD materi perkalian dan pembagian bilangan pecahan. Penelitian ini merupakan penelitian pengembangan Research and Development (R\&D) adaptasi Dick and Carey. Subjek pada penelitian ini adalah siswa kelas V SD N Lempuyangan I Yogyakarta. Pengumpulan data dilakukan dengan lembar validasi ahli, lembar komentar siswa, lembar observasi guru, dan tes. Data dari instrumen dianalisis menggunakan analisis deskriptif skala lima dan analisis Uji T. Hasil penelitian menunjukkan bahwa media travel game layak digunakan untuk pembelajaran matematika kelas V SD materi perkalian dan pembagian bilangan pecahan. Hasil kelayakan media travel game oleh ahli materi, media dan praktisi mendapatkan penilaian "baik". Hasil kelayakan media travel game oleh siswa dalam tahap one to one evaluation mendapatkan penilaian "baik", tahap small group evaluation mendapatkan penilaian "baik", dan tahap field evaluation mendapatkan penilaian "baik sekali". Media travel game efektif digunakan untuk pembelajaran matematika kelas V SD materi perkalian dan pembagian bilangan pecahan dengan perolehan hasil $t_{\text {hitung }}=-9,764$.
\end{abstract}

Kata kunci: pengembangan, media travel game, matematika

\begin{abstract}
This study aims to developing a travel game media that is known: (1) the appropriateness of travel game media for mathematics learning in Grade $V$ of the elementary school for the topic of multiplication and division of fractions, and, (2) the effectiveness of the application of travel game media in mathematics learning in Grade $V$ of the elementary school for the topic of multiplication and division of fractions. This was a research and development $(R \& D)$ study adapted from Dick \& Carey. The research subjects comprised Grade V students of SD Negeri Lempuyangan I Yogyakarta. The data were collected through an expert validation sheet, a student comment sheet, a teacher observation sheet, and a test. Data from the instrument were analyzed using descriptive analysis of the five-Test and analysis of the $T$ scale. The results showed that the media used to travel a decent game fifth grade elementary math learning material multiplication and division of fractions. The results of the assessment of the appropriateness of the travel game media by the material and media experts and practitioners show that the media are good. The results of the assessment of the appropriateness of the travel game media by students in the one to one evaluation show that they are good, in the small group evaluation they are good, and in the field evaluation they are very good. Travel media game effectively used for teaching elementary mathematics class $V$ material multiplication and division of fractions with the acquisition results $\mathbf{t}_{\text {hitung }}=-9,764$.
\end{abstract}

Keywords: development, Travel Game, Learning Mathematics 


\section{Pendahuluan}

Matematika merupakan salah satu ilmu dasar yang mendukung perkembangan ilmu pengetahuan dan teknologi lainnya. Pengalaman siswa belajar matematika sangat penting untuk memecahkan masalah dalam kehidupan seharihari. Menurut Liebeck dalam bukunya Abdurrahman (2003, p.253), ada dua macam hasil belajar yang harus dikuasai siswa yaitu, perhitungan matematis dan penalaran matematis. Kedua hasil belajar tersebut penting bagi siswa selain untuk memecahkan masalah dalam kehidupan sehari-hari juga untuk mempelajari bidang studi lain, karena hampir pada semua bidang studi memerlukan matematika. Seperti yang diungkapkan Booker (2009, p.37) bahwa

mathematics can be thought of many ways. It can be thought of in terms of its content such as number, space and measurement; the process for computing, constructing or measuring; or its uses in applications accross a diverse range of situations.

Penanaman konsep yang benar pada pembelajaran matematika di Sekolah Dasar (SD) sangat ditekankan karena merupakan konsep dasar yang harus dikuasai siswa untuk memahami konsep matematika ke jenjang berikutnya. Hal ini terkait adanya topik atau konsep prasyarat sebagai dasar untuk memahami topik atau konsep selanjutnya (Heruman, 2008, p.4). Pendidikan dasar merupakan jenjang pendidikan yang sangat penting dan mendasar dalam upaya menghasilkan manusia Indonesia yang berkualitas serta mempunyai peranan besar baik dalam menyiapkan siswa terjun dalam masyarakat maupun untuk memenuhi persyaratan mengikuti jenjang pendidikan menengah. Oleh karena itu pembelajaran matematika di SD akan menentukan hasil pendidikan di jenjang selanjutnya.

Kualitas hasil pendidikan matematika dapat diukur melalui hasil nilai UN (Ujian Nasional). Statistik hasil UN SMP tahun 2011 mengalami penurunan rata-rata nilai dari 7,53 menjadi 7,30 (Puspendik, 2012). Kenyataan ini menunjukkan lemahnya penguasaan matematika siswa SMP di Indonesia yang berujung pangkal pada lemahnya penguasaan matematika di SD. Lemahnya penguasaan matematika di SD disebabkan oleh beberapa faktor, diantaranya kesulitan siswa dalam pemahaman konsepkonsep matematika, tidak tersedianya alat peraga matematika, dan tidak adanya media yang mendukung pembelajaran.
Lemahnya penguasaan matematika diperparah dengan sedikitnya kesempatan guru untuk memperbaharui pembelajaran, misalnya dengan membuat media permainan pembelajaran yang menarik bagi siswa. Keterbatasan waktu seorang guru kelas di SD dikarenakan beban mengajar tidak hanya satu mata pelajaran melainkan hampir semua mata pelajaran. Guru yang mengampu lebih dari satu mata pelajaran konsekuensinya harus menyiapkan kelengkapan administrasi yang lebih dari satu/rangkap yaitu program tahunan, program semester, silabus, pemetaan dan Rencana Pelaksanaan Pembelajaran (RPP). Terlebih lagi di SD tidak ada pegawai administrasi khusus, sebagian guru merangkap sebagai pegawai administrasi (keuangan sekolah dan tabungan siswa), pengurus dana Bantuan Operasional Sekolah (BOS), penjaga perpustakaan, dan penjaga koperasi siswa sehingga guru bertahan pada proses pembelajaran yang selama ini diterapkan meski penguasaan matematika siswa masih lemah.

Lemahnya penguasaan matematika siswa juga diakui guru kelas V SD N Lempuyangan I Yogyakarta. Berdasarkan wawancara yang dilakukan pada tanggal 6 Agustus 2011, diperoleh informasi bahwa siswa mengalami kesulitan menyelesaikan soal dari gabungan beberapa materi pelajaran. Pada tiap bab materi siswa dapat menyelesaikan soal meski penjelasan yang diberikan pada siswa harus diulang-ulang. Namun ketika siswa dihadapkan pada soal dari gabungan beberapa materi, sebagian besar siswa bingung dan tidak tahu cara penyelesaiannya. Dari hasil analisis yang dilakukan guru, materi yang paling kurang dikuasai siswa adalah pecahan. Dalam setiap latihan soal sumatif, biasanya siswa yang dapat menyelesaikan soal dengan baik hanya 10 sampai 16 siswa dari siswa yang berjumlah 34 siswa. Hal ini berarti kurang dari 50\% siswa yang mampu menyelesaikan soal pecahan dengan benar.

Guru Kelas V SD N Lempuyangan I juga mengungkapkan bahwa di sekolah belum tersedia media pembelajaran matematika yang menarik bagi siswa. Di sekolahan hanya ada beberapa alat peraga bangun ruang yang sudah tidak layak pakai dan beberapa kerangka bangun ruang. Kelas tersebut pernah mendapat bantuan dari salah satu dosen (di sebuah perguruan tinggi swasta) media garis bilangan dari kain flanel dan kartu bilangan akar pangkat dua. Media tersebut sudah cukup menarik bagi siswa. Pada saat proses pembelajaran siswa lebih bersemangat dan hasilnya pun meningkat, akan tetapi 
ketika menyelesaikan soal mid semester ataupun soal akhir semester, siswa bingung harus menggunakan rumus yang mana dan strategi untuk prioritas penyelesaian soal juga belum diputuskan. Kejadian ini dirasakan guru selalu berulang pada setiap tahunnya. Keterbatasan media pembelajaran seharusnya membangkitkan kreatifitas guru untuk menciptakan media pembelajaran yang sederhana.

Media pembelajaran berupa alat peraga sederhana sudah digunakan dalam pembelajaran matematika. Peneliti mencatat hasil observasi pada pembelajaran di kelas, siswa diminta mengukur, memotong kertas dan menghitung luas suatu bangun saat proses pembelajaran berlangsung. Soal latihan diberikan satu persatu, masing-masing siswa mengerjakan sesuai dengan petunjuk guru, selesai langsung dinilai. Dalam dua jam pelajaran hanya sekitar lima soal yang bisa selesai dikerjakan. Penanaman konsep pada siswa sudah baik, hanya saja butuh waktu yang lama dalam praktik pembelajarannya. Waktu efektif yang tersedia untuk pembelajaran matematika dirasakan guru tidak sebanding dengan jumlah materi matematika. Guru menitikberatkan pada penanaman konsep dengan mengesampingkan keterampilan matematika agar semua materi dapat tersampaikan. Terkadang guru harus menambah jam di luar jam pelajaran efektif untuk mengasah keterampilan matematika. Waktu dan beban tugas menyebabkan guru tidak bisa terlalu banyak meluangkan waktu di luar jam pelajaran untuk memberikan latihan soal yang beragam pada siswa. Konsekuensinya, siswa tidak terbiasa berfikir cepat dan keterampilan matematikanya lemah.

Keterampilan matematika siswa yang masih kurang, akan melemahkan pemahaman konsep yang sudah diperoleh dari proses pembelajaran. Kurangnya keterampilan matematika siswa dan tidak adanya media pembelajaran yang menarik merupakan faktor yang mempengaruhi rendahnya hasil ujian mid semester dan ujian akhir semester. Kenyataannya menunjukkan bahwa tidak banyak siswa yang terampil dalam perhitungan matematika. Oleh karena itu perlu dikembangkan media pembelajaran yang bisa dibuat atas kreatifitas guru sendiri dengan beberapa tambahan yang perlu dibeli. Media ini tentunya dapat merangsang siswa untuk terbiasa berfikir cepat, tepat dan akurat tanpa mengesampingkan ketertarikan siswa untuk terus belajar matematika.
Metode dan media pembelajaran yang diterapkan dalam proses pembelajaran matematika diusahakan sesuai dengan usia siswa yang senang bermain. Ketepatan dalam memilih metode dan media menjadi suatu keharusan bagi guru dalam upaya menanamkan konsep matematika pada siswa. Penyajian pembelajaran dalam bentuk permainan mampu membangkitkan semangat untuk terus belajar matematika. Siswa melakukan aktivitas bermain secara tidak sadar sekaligus juga sedang melaksanakan proses pembelajaran. Permainan yang bisa diterapkan di SD salah satunya adalah dengan mengembangkan media pembelajaran travel game.

Travel Game adalah media pembelajaran yang berwujud benda nyata yang memungkinkan siswa belajar secara aktif dengan metode kooperatif. Travel game memaksimalkan kegiatan belajar siswa dalam kelompok-kelompok kecil dan saling belajar bersama. Siswa tertantang untuk berfikir cepat, tepat, akurat agar tidak tertinggal langkah dari lawan mainnya. Siswa dihadapkan dengan soal yang beragam dari materi yang sudah dipelajari sehingga menguatkan pemahaman konsep dan keterampilan matematika.

Dalam pembelajaran ini, setelah siswa memahami konsep materi matematika yang diberikan oleh guru, siswa bergabung dalam kelompok-kelompok kecil untuk bermain travel game. Pada proses bermain dan belajar secara tidak sadar akan terjadi diskusi antarpemain. Ketika salah satu pemain menyebutkan jawaban yang salah, maka pemain yang lain akan menyalahkan dan memberikan argumen penyelesaian soal yang benar begitu juga sebaliknya pemain akan mempertahankan hasil penyelesaian soal sehingga sekelompok pemain yang terlibat akan menemukan jawaban yang tepat dan akurat dari hasil diskusi tersebut.

Bermain adalah suatu kegiatan yang serius tetapi mengasyikkan bagi anak (Semiawan, 2008, p.20). Dalam permainan siswa dibawa dalam suasana menyenangkan sesuai dengan kemauan sendiri. Pembelajaran yang dikemas dengan permainan dapat dijadikan alternatif pembelajaran yang menarik bagi siswa dengan adanya suasana yang menantang, unsur kompetisi, adanya keragu-raguan tidak tahu hasil akhirnya yang akan menang dan kalah dalam permainan. Permainan dapat memberikan umpan balik langsung. Umpan balik yang secepatnya atas apa yang dilakukan akan memungkinkan proses belajar jadi lebih efektif (Sadiman, 2009, pp.78-81). 
Media pembelajaran travel game dikemas dengan jumlah soal-soal yang bervariasi dari materi perkalian dan pembagian bilangan pecahan. Soal yang beragam memberi kesempatan siswa untuk terbiasa mengingat kembali materi yang sudah pernah diterimanya dalam waktu yang singkat dalam bentuk kompetisi. Siswa terbiasa untuk menyelesaikan soal yang dihadapi tanpa bisa menghindar dari soal yang dirasa sulit. Siswa akan tertantang memenangkan travel game dan segera menyelesaikan. Kegiatan semacam ini membantu siswa belajar untuk menargetkan penyelesaian soal sesuai dengan waktu yang tersedia dan memudahkan siswa menghadapi soal yang beragam sehingga soal mid semester ataupun soal ujian akhir semester tidak menjadi masalah bagi siswa.

Dalam rangka mempersiapkan menghadapi ujian semester, guru perlu menyiapkan pembelajaran yang menyenangkan dan bermakna bagi siswa. Pembelajaran yang menyenangkan dan bermakna dapat diwujudkan dengan penyediaan media permainan. Media permainan yang tepat dan sesuai dengan siswa di SD Lempuyangan 1 Yogyakarta salah satunya media travel game. Namun guru kesulitan untuk menyediakan media travel game. Guru kesulitan mengembangkan kreativitasnya agar kesulitan siswa dalam pembelajaran matematika dapat teratasi. Untuk mengatasi masalah ini peneliti melakukan penelitian dengan judul "Mengembangkan Media Travel Game untuk Pembelajaran Perkalian dan Pembagian Bilangan Pecahan Matematika Sekolah Dasar Kelas V".

Permasalahan yang dihadapi guru kelas V di SD N Lempuyangan 1 Yogyakarta diantaranya: materi pecahan merupakan materi yang paling sulit bagi siswa, belum tersedianya media pembelajaran berupa permainan untuk mata pelajaran matematika dalam mengatasi lemahnya kemampuan berhitung matematika, guru kesulitan mengembangkan kreativitasnya untuk membuat media pembelajaran yang menyenangkan berupa permainan, siswa belum dibiasakan berfikir cepat, tepat dan akurat jika dihadapkan dengan soal dalam jumlah banyak sehingga tidak bisa menyelesaikan sesuai dengan waktu yang tersedia. Penelitian ini dibatasi pada masalah belum tersedianya media dan guru belum mengembangkan kreativitasnya untuk membuat media pembelajaran yang menyenangkan berupa permainan.

Penelitian ini difokuskan pada pengembangan media travel game khususnya pada mata pelajaran matematika kompetensi dasar mengalikan dan membagi berbagai bentuk pecahan. Penelitian ini bertujuan untuk mengembangkan kelayakan media travel game dan mengetahui efektivitas media travel game yang dikembangkan dalam pembelajaran matematika kompetensi dasar mengalikan dan membagi berbagai bentuk pecahan.

Dalam penelitian ini definisi operasional untuk pembelajaran matematika merupakan proses yang mengandung serangkaian perbuatan guru dan siswa atas dasar hubungan timbal balik dengan tujuan agar siswa dapat belajar matematika dengan suasana hati yang menyenangkan, sedangkan media Pembelajaran merupakan alat bantu untuk mengefektifkan komunikasi dan interaksi antara guru dan siswa dalam proses pembelajaran, dan untuk travel game adalah permainan yang dilakukan secara berkelompok dengan peserta maksimal empat anak, menggunakan perlengkapan papan permainan, pioner, dadu, kartu pintar, lembar jawaban kartu pintar, dadu, dan lembar jawaban dadu.

\section{Metode}

\section{Model Pengembangan}

Model pengembangan yang digunakan adalah model penelitian dan pengembangan ( $r e$ search and developement). Penelitian ini mengadaptasi model pengembangan Dick \& Carey (2005, pp.282-291).

\section{Prosedur Pengembangan}

Prosedur pengembangan melalui langkah: (1) analisis pembelajaran, (2) pengembangan desain media travel game, (3) desain uji coba produk dan revisi: one to one evaluation, small group evaluation \& field trial.

\section{Uji Coba Produk}

Sebelum diujicobakan produk divalidasi oleh dosen ahli materi yaitu Dr. Ali Mahmudi dan dosen ahli media yaitu Prof. Dr. Abdul Ghafur. Setelah divalidasi, produk diujicobakan melalui one to one evaluation, small group evaluation \& field trial.

\section{Subjek Uji Coba}

Subjek uji coba dalam penelitian ini adalah siswa Kelas V SD Negeri Lempuyangan I Yogyakarta. Untuk one to one evaluation sebanyak 8 siswa dari kelas $\mathrm{V}_{\mathrm{B}}$, small group evaluation sebanyak 12 siswa dari kelas $\mathrm{V}_{\mathrm{C}}$, dan field trial sebanyak 34 siswa. 


\section{Jenis Data}

Data kualitatif dalam penelitian ini adalah data yang diperoleh dari tanggapan mengenai aspek pembelajaran, materi, dan media dari berbagai sumber yaitu ahli materi, ahli media, guru, dan siswa. Data kuantitatif diperoleh dari hasil nilai siswa pada pretest dan posttest.

\section{Instrumen Pengumpulan Data}

Instrumen yang digunakan dalam penelitian ini adalah instrumen non tes berupa lembar validasi ahli materi, lembar validasi ahli media, lembar komentar siswa dan lembar observasi guru, dan instrumen tes berupa pretest dan posttest. Kisi-kisi untuk validasi ahli materi dapat dilihat pada tabel berikut ini.

Tabel 1.Kisi-kisi Validasi Ahli Materi

\begin{tabular}{ccl}
\hline No & Aspek & \multicolumn{1}{c}{ Indikator } \\
\hline 1 & Papan & (1) petunjuk cara bermain, (2) \\
travel & aturan permainan, (3) susunan \\
& game & petunjuk bermain, (4) kejelasan \\
& & langkah-langkah bermain, (5) \\
& & ketepatan informasi petunjuk ber- \\
& & main, (6) kesesuain urutan perma- \\
& & inan, (7) kesesuaian permainan \\
& & dengan materi yang dikembang- \\
& & kan, (8) kejelasan informasi yang \\
& & disampaikan, dan (9) tampilan \\
& papan permainan \\
jawaban & (1) cakupan materi yang diberi- \\
dadu \& & kan, (2) penggunaan pemilihan \\
kartu & kata penyampaian konsep, (3) \\
pintar & pemberian warna kotak dan alur \\
& konsep, (4) kesesuaian soal de- \\
& ngan materi/konsep, (5) kejelasan \\
& informasi yang disampaikan, (6) \\
& kesesuaian SK, KD, indikator dan \\
& tes.
\end{tabular}

Kisi-kisi untuk instrumen ahli materi ada tiga aspek yaitu pembelajaran, materi dan media. Untuk indikator aspek pembelajaran yaitu: (1) kejelasan rumusan kompetensi belajar, (2) ketepatan rencana pembelajaran, (3) urutan penyampaian materi, (4) pemberian contoh dalam penyajian, (5) pemberian latihan pemahaman konsep, (6) isi tes pengukuran kemampuan siswa, (7) kejelasan penyampaian materi, (8) memberikan motivasi kepada siswa, (9) respon terhadap jawaban pertanyaan siswa yang benar, (10) respon terhadap jawaban pertanyaan siswa yang salah, (11) teknik mendorong siswa berkomunikasi dalam kelompok, (12) memberikan kesempatan kepada siswa menyampaikan pendapat, (13) cara memotivasi siswa dalam bermain agar tetap belajar.

Kisi-kisi untuk ahli media dapat dilihat pada tabel berikut ini.

Tabel 2.Kisi-kisi Validasi Ahli Materi

\begin{tabular}{cll}
\hline No & Aspek & \multicolumn{1}{c}{ Indikator } \\
\hline 1 & Petunjuk & (1) Petunjuk cara bermain, (2) \\
& Pengguna & Aturan permainan, (3) Susunan \\
an travel & pame & petunjuk bermain, (4) Kejelasan \\
& & langkah-langkah bermain, (5) \\
& & Ketepatan informasi petunjuk \\
& bermain, (6) Kesesuain urutan \\
& permainan, (7) Kesesuaian \\
& permainan dengan materi yang \\
& dikembangkan, (8) Kejelasan \\
& informasi yang disampaikan, (9) \\
& Tampilan papan permainan, (10) \\
& Tampilan petunjuk secara utuh \\
& (1) Tampilan papan permainan, \\
game & (2) Pemilihan warna background \\
& kotak, (3) Kesesuaian penempat- \\
& an gambar, (4) Besar ukuran ko- \\
& tak, (5) Pemilihan bentuk huruf, \\
& (6) Ukuran huruf, (7) Pemilihan \\
& warna huruf, (8) Ketepatan tata \\
& letak/layout,(9) Ketepatan peng- \\
& gunaan gambar.
\end{tabular}

Indikator untuk aspek materi yaitu: (1) kemasan materi dalam permainan, (2) pemilihan bahasa dalam penyampaian materi, (3) tingkat kesulitan materi, (4) kesesuaian materi dengan soal tes, (5) kesesuaian materi dalam kehidupan sehari-hari.

Indikator untuk aspek media yaitu: (1) kejelasan petunjuk permainan, (2) kemudahan melakukan permainan, (3) kejelasan jenis dan ukuran huruf, (4) komposisi gambar dan kombinasi warna, (5) kualitas tampilan gambar, (6) kejelasan informasi aktivitas, dan (7) kualitas tampilan papan permainan.

Sedangkan untuk angket siswa ada dua aspek yaitu materi dan media. Untuk kisi-kisi tiap aspek dapat dilihat pada tabel berikut ini.

Tabel 3.Kisi-kisi Instrumen Angket Siswa

\begin{tabular}{|c|c|c|}
\hline No & Aspek & Indikator \\
\hline 1 & Materi & $\begin{array}{l}\text { (1) kejelasan soal pada papan travel } \\
\text { game,(2) kejelasan soal pada kartu } \\
\text { pintar, (3) kesesuaian tes dengan } \\
\text { materi matematika }\end{array}$ \\
\hline 2 & Media & $\begin{array}{l}\text { (1) kejelasan aturan permainan, (2) } \\
\text { kejelasan tulisan, (3) ukuran dan } \\
\text { tampilan papan permainan }\end{array}$ \\
\hline
\end{tabular}




\section{Teknik Analisis Data}

Data kualitatif yang berupa kritik dan saran yang dikemukakan ahli media, ahli materi, guru dan peserta didik dianalisis dengan teknik persentase dan kategorisasi sedangkan untuk mengetahui efektivitas produk, skor pretest dan posttest dibandingkan dengan Uji T sampel berpasangan (paired-samples $\mathrm{t}$ test). Media travel game dinyatakan layak jika nilai produk dari data kualitatif minimal " $\mathrm{B}$ " dan pembelajaran efektif jika $t$ hitung $<\mathrm{t}$ tabel.

\section{Hasil Penelitian dan Pembahasan}

Data Cara Pengembangan

Pengembangan media travel game diawali dengan melakukan Analisis kebutuhan siswa pada bulan April-Juni 2012 di SD N Lempuyangan Yogyakarta. Analisis kebutuhan diperoleh dari hasil observasi kelas, wawancara guru dan siswa. Hasil analisis dibahas dalam dua kriteria yaitu analisis siswa dan analisis tugas. Adapun data yang diperoleh dari analisis kebutuhan yaitu:

\section{Analisis Siswa}

Analisis dilakukan terhadap kelas $\mathrm{V}$ di SDN Lempuyangan Yogyakarta, yaitu kelas $V_{A}$ dan $\mathrm{V}_{\mathrm{C}}$. Berdasarkan analisis terhadap hasil observasi diketahui bahwa masing-masing kelas memiliki karakteristik yang hampir sama. Kelas $\mathrm{V}_{\mathrm{A}}$ berjumlah 34 siswa, $\mathrm{V}_{\mathrm{C}} 32$ siswa dan hasil wawancara dengan guru kelas tersebut diketahui bahwa sebagian besar siswa mengalami kesulitan menyelesaikan soal sesuai dengan target waktu yang diberikan. Siswa memerlukan waktu lama ketika mengerjakan soal mid ataupun soal ujian akhir semester. Siswa kesulitan menentukan langkah penyelesaian soal dan kurang terampil dalam berhitung. Hal ini mengakibatkan sebagian besar siswa tidak dapat menyelesaikan soal mid ataupun semester dengan tepat waktu. Siswa belum mempunyai strategi menyelesaikan soal matematika dengan cepat, tepat, dan akurat. Hasil ulangan mid ataupun ulangan akhir semester pun rendah. 17 dari 34 siswa harus mengikuti remidi karena nilai yang diperoleh belum mencapai standar ketuntasan minimal yang sudah ditentukan.

Pada proses pembelajaran, guru kelas mengalami kesulitan untuk memantau siswa yang berjumlah 34 siswa dan memastikan bahwa setiap siswa menghitung dan menyelesaikan sendiri soal-soal latihan yang diberikan. Guru memberikan soal-soal dengan cara klasikal be- lum pernah dikemas dalam bentuk permainan. Hal ini mengakibatkan siswa kurang tertantang untuk menyelesaikan latihan soal yang diberikan. Soal-soal latihan untuk mengasah keterampilan berhitung dibiarkan terbengkali yang penting siswa sudah merasa bisa mengerjakan satu atau dua soal, maka siswa menganggap soal yang lain tidak perlu dikerjakan.

Guru kelas mengungkapkan bahwa materi matematika yang harus disampaikan banyak dan membutuhkan waktu yang tidak sedikit. Keterampilan siswa dalam berhitung juga berbeda-beda, kadang juga terbebani ketidaktuntasan penguasaan materi siswa dari kelas sebelumnya. Guru sebenarnya sudah menekankan pada penanaman konsep, namun untuk keterampilan berhitung belum bisa diatasi karena keterbatasan waktu dalam pembelajaran matematika. Hal ini menyebabkan keterampilan berhitung siswa kurang terasah. Diharapkan dengan adanya media travel game yang mengutamakan ketepatan dan kecepatan berhitung karena siswa harus berlomba mengumpulkan poin dan memenangkan permainan, maka siswa terbiasa menyelesaikan soal dengan cepat dan tepat.

\section{Analisis Tugas}

Berikut ini tabel analisis materi pecahan.

Tabel 4.Analisis Tugas

\begin{tabular}{cll}
\hline No & \multicolumn{1}{c}{$\begin{array}{c}\text { Bagian } \\
\text { Analisis }\end{array}$} & \multicolumn{1}{c}{ Hasil Analisis } \\
\hline 1 Standar & 5.Menggunakan pecahan dalam \\
& Kompetensi & memecahkan masalah \\
2 Kompetensi & 5.3. Mengalikan dan membagi \\
Dasar & berbagai bentuk pecahan. \\
3 Indikator & Siswa dapat: (1) Mengalikan pe- \\
& cahan biasa dengan pecahan bia- \\
& sa, (2) Mengalikan pecahan cam- \\
& puran dengan pecahan biasa, (3) \\
& Mengalikan pecahan desimal de- \\
& ngan pecahan biasa, (4) Mengali- \\
& kan persen dengan pecahan biasa, \\
& (5) Membagi bilangan asli de- \\
& ngan bentuk pecahan, (6) Mem- \\
& bagi pecahan biasa dengan pecah- \\
& an biasa, (7) Membagi pecahan \\
& campuran dengan pecahan biasa, \\
& (8) Membagi pecahan desimal de- \\
& ngan pecahan biasa, (9) Menyele- \\
& saikan soal cerita perkalian dan \\
& pembagi-an bentuk pecahan \\
\hline &
\end{tabular}


Perencanaan dan Pengembangan Papan Travel Game

Papan travel game terdiri dari papan travel game, dadu, pioner, gelas pengocok da$\mathrm{du}$, kartu pintar, petunjuk penggunaan.

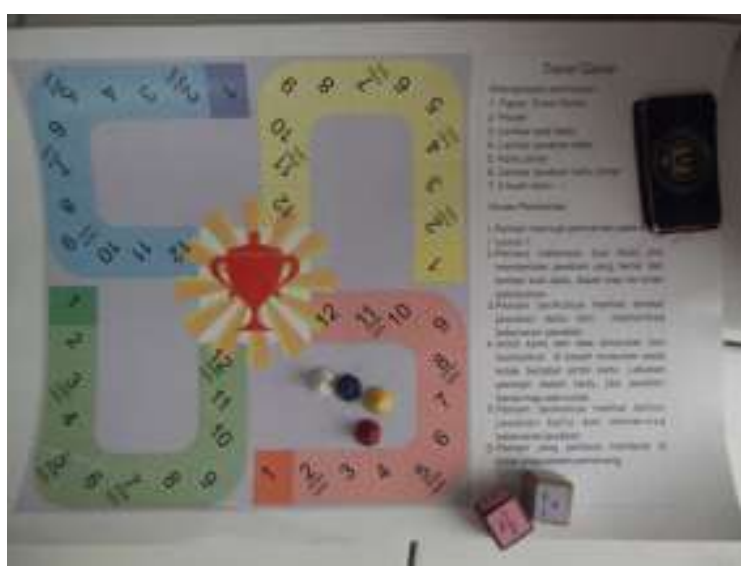

Gambar 1.Draf Papan Travel Game

Papan sebelum dikembangkan terbuat dari kertas karton tipis ukuran kertas A4 yang dilaminating. Kotak pijakan pioner berbentuk lurus memanjang dengan langkah maju. Warna kotak polos dan berisi tulisan start, ambil kartu, dan finish. Papan travel game draf dikembangkan terbuat dari kertas vinil tebal ukuran A3 dan dicetakkan dipercetakan. Kotak pijakan lintasan pioner masing-masing pemain di lingkungan searah jarum jam. Warna lintasan dibuat berbeda tiap pemain agar mudah dibedakan. Tiap kotak lintasan diberi tulisan start, ambil kartu, finish dan diberi nomor kotak agar jelas arah langkah pioner. Pada kotak finish diganti gambar piala yang menandakan kemenangan salah satu pemain yang berarti langkah pioner sudah selesai.

\section{Dadu}

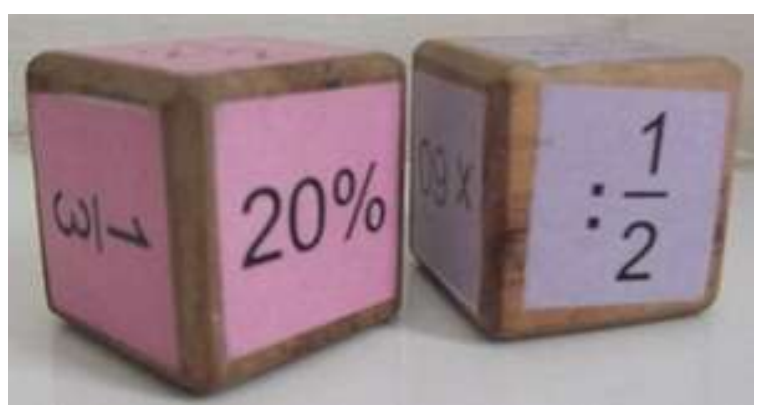

Gambar 2.Draf Dadu Travel Game

Dadu sebelum dikembangkan tiap sisi dadu berisi tulisan satu angka dari angka 1-6. Angka pada dua dadu yang nampak draf dilambungkan, maka akan terdapat sepasang angka dari kedua dadu. Contoh penggunaannya: jika angka yang nampak pada dadu pertama angka 1 dan dadu kedua angka 4, maka soal yang dikerjakan adalah soal pada lembar soal dadu di kotak pertemuan antara kolom pertemuan dadu bilangan 4 dan 1 . Tulisan pada dadu ditulis menggunakan spidol permanen.

Dadu draf dikembangkan, pada ruas dadu ditumpulkan agar tidak melukai siswa. Dadu yang pertama berisi tulisan bilangan pecahan sedangkan dadu kedua berisi operasi bilangan beserta bilangan pecahan. Cara penggunaannya: jika kedua dadu yang dilambungkan akan nampak bilangan dan operasi bilangan disertai bilangan, maka kedua bilangan yang ada pada dua dadu tersebut dioperasikan sesuai dengan operasi yang tertulis.

\section{Pioner}

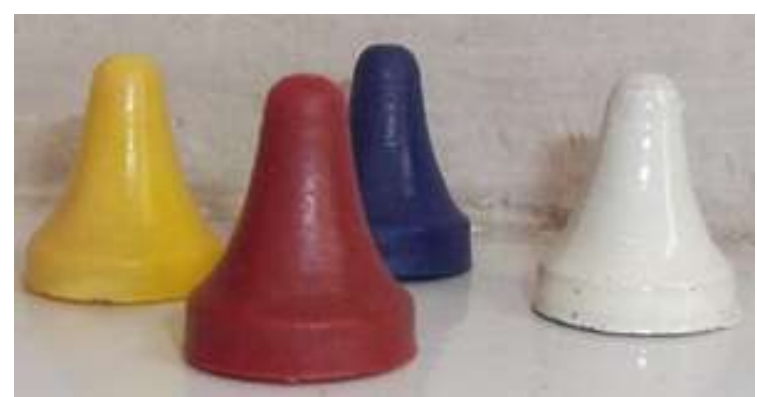

\section{Gambar 3.Draf Pioner Travel Game}

Pioner adalah lambang berupa benda untuk seorang pemain. Pioner ini yang digerakkan menempati kotak di papan travel game.

\section{Gelas Pengocok Dadu}

Sebelum media travel game dikembangkan, dadu hanya dikocok menggunakan tangan. Dadu yang dikembangkan berukuran $3 \mathrm{~cm}$ x $3 \mathrm{~cm}$. Agar lebih mudah dalam pengocokan maka digunakan gelas pengocok dadu. Gelas pengocok dadu digunakan untuk mengocok dadu.

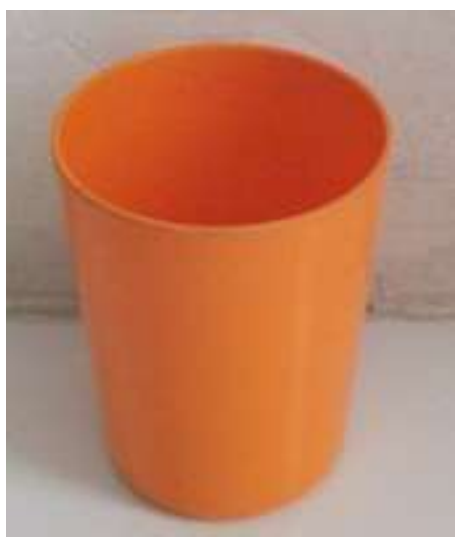

Gambar 4.Draf Gelas Pengocok Dadu 


\section{Kartu Pintar}

Kartu pintar dibuat dengan ukuran 4 $\mathrm{cm} \times 8 \mathrm{~cm}$, agar tulisan soal ataupun perintah bisa dituliskan dalam font yang besar sehingga terlihat jelas dan mudah dibaca oleh siswa SD. Ukuran ini juga memudahkan siswa untuk memegang ataupun membolak-balik kartu. Bagian sudut kartu dibuat melengkung tidak lancip agar tidak menusuk atau melukai permukaan kulit saat memegang kartu.

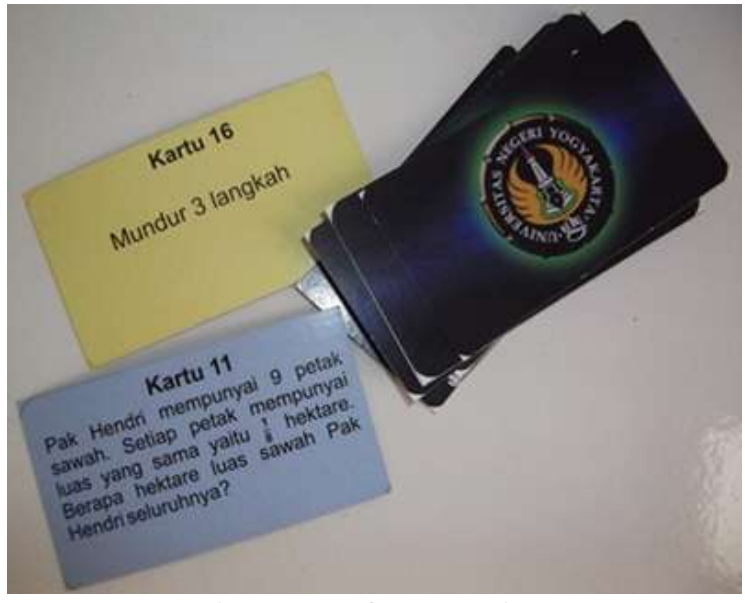

Gambar 5.Draf Kartu Pintar

Kartu travel game berisi kartu soal dan kartu ketidakpastian. Nomor kartu 1-14 berisi soal dan nomor kartu 15-20 berisi ketidakpastian. Kartu ini diambil pemain jika pemain menempati lajur papan travel game "ambil kartu".

\section{Petunjuk Penggunaan}

Petunjuk penggunaan yang sudah dikembangkan terdiri dari kelengkapan permainan dan aturan permainan. Kelengkapan permainan diantaranya (1) papan travel game, (2) pioner, (3) lembar soal dadu, (4) lembar jawaban dadu, (5) kartu pintar, (6) lembar jawaban kartu pintar, dan (7) dua buah dadu.

Aturan permainan yaitu: (1) Pemain memulai permainan pada kotak nomor satu; (2) Pemain melempar dua dadu, jika memberikan jawaban yang benar dari lembar soal dadu, dapat maju ke kotak selanjutnya, (3) Pemain berikutnya melihat lembar jawaban dadu dan memeriksa kebenaran jawaban, (4) ambil kartu dari atas tumpukan dan kembalikan di bawah tumpukan pada kotak berlabel ambil kartu. Lakukan perintah dalam kartu, jika jawaban benar maju satu kotak, (5) pemain berikutnya melihat lembar jawaban kartu dan memeriksa kebenaran jawaban, dan (6) pemain yang pertama mendarat di kotak piala adalah pemenang.

\section{Lembar Jawaban Dadu}

Lembar jawaban dadu dituliskan dalam selembar kertas HVS A4. Lembar jawaban dadu berfungsi acuan untuk mengoreksi hasil perhitungan pemain dari operasi bilangan yang muncul pada dadu. Pemain yang memperoleh giliran melambungkan dadu berikutnya, bertugas mengoreksi jawaban pemain dari hasil perhitungan operasi yang muncul dari dadu. Jika pemain memberikan jawaban yang benar (sama dengan lembar jawaban dadu), maka pemain maju satu kotak. Namun, jika jawaban yang diberikan pemain salah, maka pemain tetap di kotak tersebut. Lembar jawaban kartu pintar dapat dilihat di lampiran halaman.

\section{Lembar Jawaban Kartu Pintar}

Lembar jawaban kartu pintar dituliskan dalam selembar kertas HVS A4. Pemain yang memperoleh giliran melambungkan dadu berikutnya, bertugas mengoreksi jawaban pemain sebelumnya yang memperoleh kartu pintar sisi soal dengan cara melihat lembar jawaban kartu pintar. Jika pemain memberikan jawaban yang benar (sesuai dengan lembar jawaban kartu pintar), maka pemain maju satu kotak. Namun, jika jawaban yang diberikan pemain salah, maka pemain tetap di kotak tersebut. Lembar jawaban kartu pintar dapat dilihat di lampiran halaman.

Lembar Soal pretest sama dengan soal posttest. Lembar soal pretest dan soal posttest disusun berdasarkan kisi-kisi.

\section{Analisis Data}

Media travel game yang sudah dirancang divalidasi ahli materi dan ahli media. Berikut ini tabel rekapitulasi hasil nilai validasi ahli materi dan ahli media.

Tabel 5.Skor Validasi Ahli Materi dan Ahli Media Travel Game

\begin{tabular}{cccc}
\hline No & Validator & Skor Rata-rata & Kategori \\
\hline 1 & Ahli Materi & 3,73 & Baik \\
2 & Ahli Media & 3,61 & Baik \\
\hline
\end{tabular}

Dari hasil penilaian validasi diperoleh diagram berikut ini. 


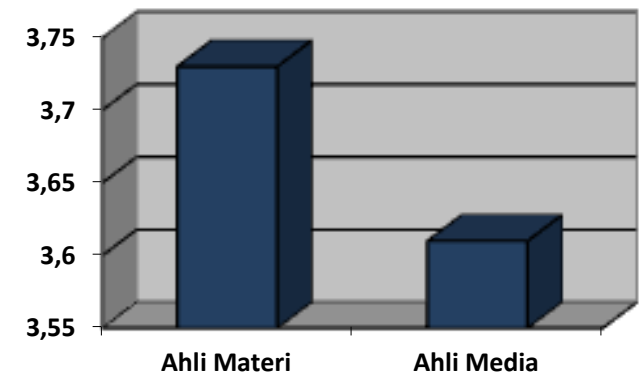

Gambar 6. Diagram Skor Validasi Ahli Materi dan Ahli Media

Berdasarkan skala penilaian skor rata-rata perolehan nilai ahli materi dan ahli media termasuk dalam kriteria "Baik/Layak". Kriteria "B" menunjukkan bahwa media travel game sudah layak dan siap digunakan untuk pembelajaran matematika kelas $\mathrm{V}$ materi perkalian dan pembagian bilangan pecahan.

Media travel game yang sudah divalidasi dan direvisi oleh ahli diujicobakan pada siswa kelas V SDN Lempuyangan 1 Yogyakarta. Hasil angket penilaian siswa terhadap media travel game direkapitulasi sebagai berikut ini.

Tabel 6. Skor Angket Penilaian Siswa Terhadap Media Travel Game

\begin{tabular}{cccc}
\hline No & $\begin{array}{c}\text { Tahapan Uji } \\
\text { Coba }\end{array}$ & Skor Rata-rata & Kategori \\
\hline 1 & $\begin{array}{c}\text { one to one } \\
\text { evaluation }\end{array}$ & 3,54 & Baik \\
2 & $\begin{array}{c}\text { small group } \\
\text { evaluation }\end{array}$ & 3,63 & Baik \\
3 & field trial & 4,28 & $\begin{array}{c}\text { Baik } \\
\text { Sekali }\end{array}$ \\
\hline
\end{tabular}

Hasil angket tiap aspek angket siswa dapat dilihat pada diagram berikut ini:

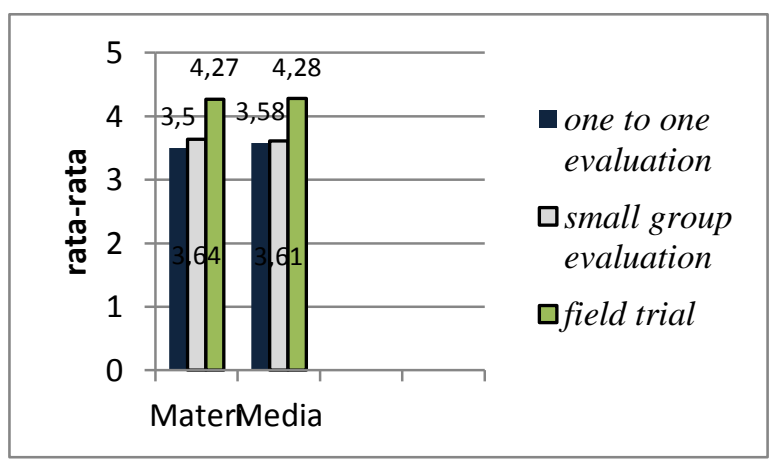

Gambar 7. Diagram Batang Tiap Aspek Hasil Angket Siswa
Secara keseluruhan nilai dapat dilihat pada diagram di bawah ini.

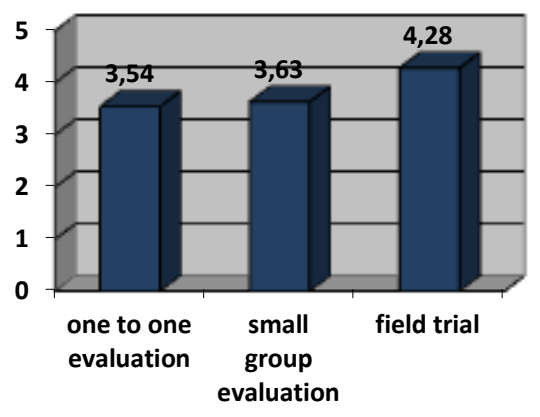

Gambar 8. Diagram Skor Angket Penilaian Siswa Terhadap Media Travel Game

Berdasarkan skala penilaian skor ratarata perolehan nilai pada tahap one to one evaluation sebesar 3,54 termasuk dalam kriteria "Baik/Layak", small group evaluation sebesar 3,63 kriteria "Baik/Layak", dan field trial sebesar 4,28 kriteria "Baik Sekali/Sangat Layak". Hasil penilaian menunjukkan bahwa media travel game sudah layak dan siap digunakan untuk pembelajaran matematika kelas $\mathrm{V}$ materi perkalian dan pembagian bilangan pecahan.

Berikut ini hasil observasi guru dari hari pertama dan kedua :

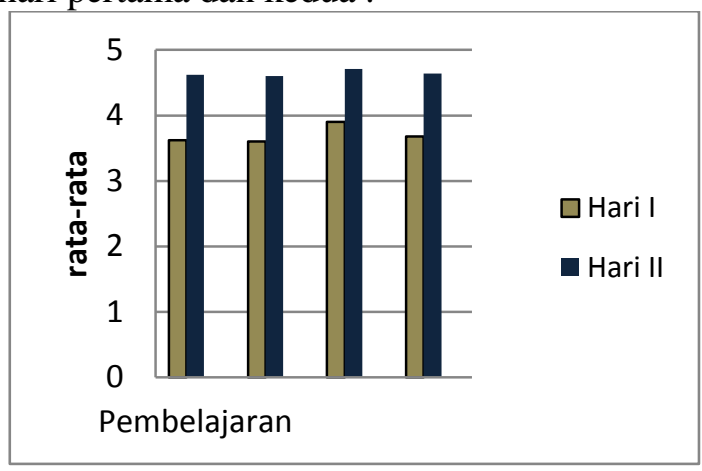

Gambar 9.Hasil Observasi Guru

Gambar tersebut menunjukkan skor rata-rata tiap aspek untuk materi travel game sebesar 3,64 dan untuk media travel game sebesar 3,61. Skor yang telah diperoleh dikonversikan menjadi nilai berdasarkan skala lima. Skor rata-rata untuk materi travel game 3,64 termasuk dalam kriteria "baik/layak", skor ratarata aspek media travel game 3,61 termasuk dalam kriteria "baik/layak", sedangkan hasil skor rata-rata untuk kedua aspek 3,63 termasuk dalam kriteria "baik/layak" dan memperoleh nilai 'B". Kriteria "baik/layak" dan perolehan nilai "B" menunjukkan bahwa media travel game sudah layak dan siap diujicobakan untuk pem- 
belajaran matematika kelas $\mathrm{V}$ materi perkalian dan pembagian bilangan pecahan.

Efektivitas pembelajaran diukur dari Uji T skor pretest dan posttest. Sebelum uji T, data diuji normalitasnya terlebih dulu.

\section{Uji Normalitas}

Uji normalitas dilakukan untuk mengetahui apakah data berdistribusi normal atau tidak. Uji normalitas dilakukan dengan software SPSS 16.0 for windows. Dalam penelitian ini pengujian normalitas menggunakan KolmogovSmirnov. Cara yang digunakan untuk melakukan interpretasi output hasil analisis dengan kriteria keputusan: bila nilai probabilitas lebih besar dari 0,05 maka populasi data yang diperoleh berdistribusi normal, sedangkan bila nilai probabilitas kurang dari 0,05 maka populasi data yang diperoleh tidak berdistribusi normal. Hasil uji normalitas dapat dilihat pada tabel berikut ini.

Tabel 7. Hasil Uji Normalitas Data Pretest dan Posttest

\begin{tabular}{cccc}
\hline \multirow{2}{*}{ Variabel } & \multicolumn{3}{c}{ Kolmogorov-Smirnov Statistic } \\
\cline { 2 - 4 } & Statistik & df & signifikansi \\
\hline pretest & 0,149 & 34 & Baik \\
posttest & 0,138 & 34 & Baik \\
\hline
\end{tabular}

Berdasarkan tabel di atas dapat dijelaskan bahwa hasil pretest dan posttest, nilai probabilitasnya berturut-turut adalah 0,051 dan 0,120 . Hal ini menunjukkan bahwa hasil data pretest dan posttest berdistribusi normal, karena nilai probabilitasnya lebih dari 0,05 . Hasil output selengkapnya dapat dilihat pada lampiran halaman 145 .

Dari hasil Uji $t$ diperoleh $t_{\text {hitung }}=-9,764$

dengan $t_{\text {tabel }}=1$,692. Karena $t_{\text {hitung }}<t_{\text {hitung }}$ maka pembelajaran matematika dengan media travel game efektif.

\section{Revisi Produk}

Revisi produk oleh ahli media berupa langkah-langkah untuk aturan permainan pada papan travel game. Aturan yang telah direvisi sebagai berikut: (1) Tiap pemain meletakkan pioner pada kotak nomor satu; (2) Urutan pemain pertama berada di lajur warna orange, kedua di lajur warna kuning, ketiga di lajur warna biru, keempat di lajur warna hijau; (3) Pemain pertama melambungkan dadu, lalu mengoperasikan bilangan yang muncul pada dadu. Pemain kedua (berikutnya) melihat lembar jawaban dadu dan memeriksa kebenaran jawaban pemain pertama. Jika pemain pertama menjawab dengan benar, pioner pemain pertama maju ke kotak selanjutnya. Jika jawaban salah, pioner pemain pertama tidak berpindah kotak; (4) Pada kotak dengan tulisan "Ambil kartu" pemain mengambil kartu dari atas tumpukan. Pemain memberikan jawaban jika kartu berisi soal (teknis pengoreksian dan langkah kebenaran jawaban sama dengan aturan nomor 3. Jika isi kartu bukan soal, pemain melakukan perintah yang ada dalam kartu. Selanjutnya kartu di letakkan di bawah tumpukan; (5) Pemain yang pertama mendarat di kotak piala adalah pemenang.

Perhatikan gambar perubahan aturan permainan pada papan travel game berikut ini.

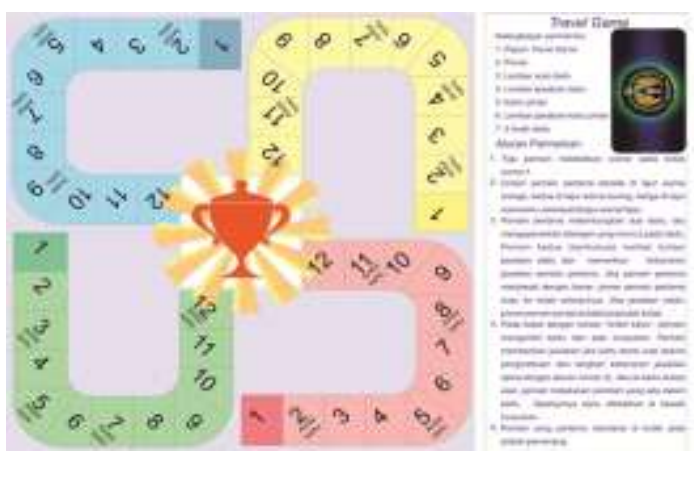

\section{Gambar 10.Aturan Permainan Revisi I}

Pada uji coba one to one evaluation bilangan pada dadu yang digunakan dalam desimal yang menghasilkan lebih dari tiga bilangan di belakang koma. Dari hasil pengamatan, siswa terlalu lama mengerjakan soal dadu. Siswa juga mengungkapkan bilangannya rumit. Hal ini akan menghambat jalannya permainan dan proses pembelajaran bisa menjadi membosankan. Berikut ini pergantian bilangan pada dadu.

Pada uji field evaluation, ada papan travel game yang melengkung dan harus digulung agar bisa datar saat diletakkan. Pioner, dadu, kartu pintar, dan lembar jawaban dadu dan lembar jawaban kartu pintar sering terceces saat digunakan. Antisipasi agar perangkat travel game sudah disiapkan, sebenarnya sudah disiapkan karet gelang untuk mengikat kartu pintar. Semua perangkat yaitu dadu, kartu pintar, pioner dan lembar jawaban dimasukkan dalam plastik, namun tetap saja masih banyak perangkat yang tercecer. Guru dan peneliti berdiskusi untuk membuat papan yang lebih tahan lama dan lebih praktis untuk menyimpan perangkat travel game. Hasil diskusi diperoleh draf papan untuk revisi IV yaitu papan travel game dibuat dari triplek dibuat dua pintu. 


\section{Kajian Produk Akhir}

Produk akhir media travel game merupakan hasil perbaikan dari revisi uji coba ahli, one to one evaluation, small group evaluation, dan field evaluation. Produk akhir media travel game untuk pembelajaran matematika kelas $\mathrm{V}$ materi perkalian dan pembagian bilangan pecahan meliputi papan travel game, dadu, pioner, kartu pintar, petunjuk penggunaan, lembar kunci jawaban dadu, lembar jawaban kartu pintar.

Berdasarkan hasil analisis data pada uji coba menunjukkan bahwa: (1) Hasil penilaian dari ahli media terhadap kelayakan media travel game mencapai skor rerata 3,61 dengan kriteria baik. Sehingga media travel game berdasarkan penilaian dari ahli media adalah layak sebagai media pembelajaran matematika; (2) Hasil penilaian dari ahli materi terhadap kelayakan multimedia interaktif mencapai skor rerata 3,73 dengan kriteria baik sehingga media travel game layak sebagai media pembelajaran matematika; (3) Hasil penilaian dari guru terhadap kelayakan media travel game mencapai skor rerata 3,73 dengan kriteria baik sehingga media travel game yang dikembangkan berdasarkan penilaian dari guru adalah layak sebagai media pembelajaran matematika.

Hasil penilaian dari siswa terhadap kelayakan media travel game pada uji coba one to one evaluation mencapai skor rerata 3,54 dengan kriteria baik, small group evaluation mencapai skor rerata 3,63 dengan kriteria baik, dan field evaluation mencapai skor rerata 4,28 dengan kriteria sangat baik. Hasil penilaian dari siswa menunjukkan bahwa media travel game yang dikembangkan berdasarkan penilaian dari siswa adalah layak sebagai media pembelajaran matematika.

Kelebihan dari media travel game adalah dapat menyediakan latihan soal yang bervariasi. Media travel game dapat dimainkan tidak terbatas waktu atau pun tempat. Media ini dapat dimainkan di rumah, pembelajaran di sekolah, dan pada waktu istirahat di sekolah. Pengemasan produk media travel game yang rapi dan ringkas mudah di bawa dan perangkatnya tidak mudah tercecer. Berikut ini gambar perangkat media travel game : draf pengembangan dan hasil Revisi IV (setelah field evaluation).

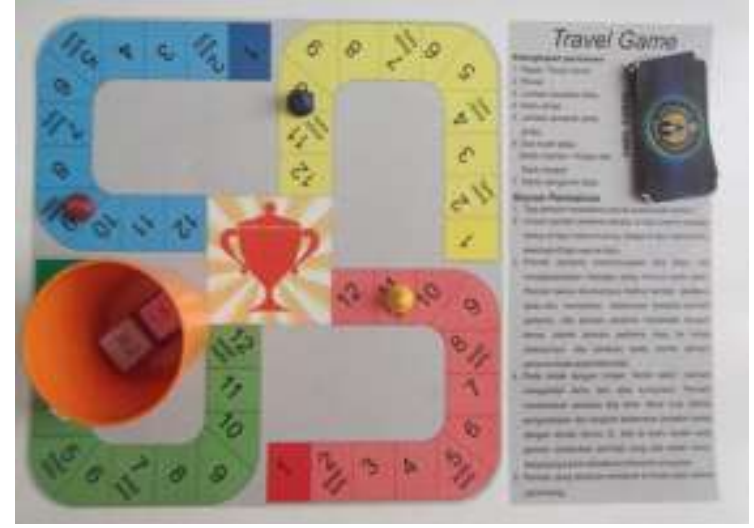

Gambar 11. Perangkat Draft Media Travel Game
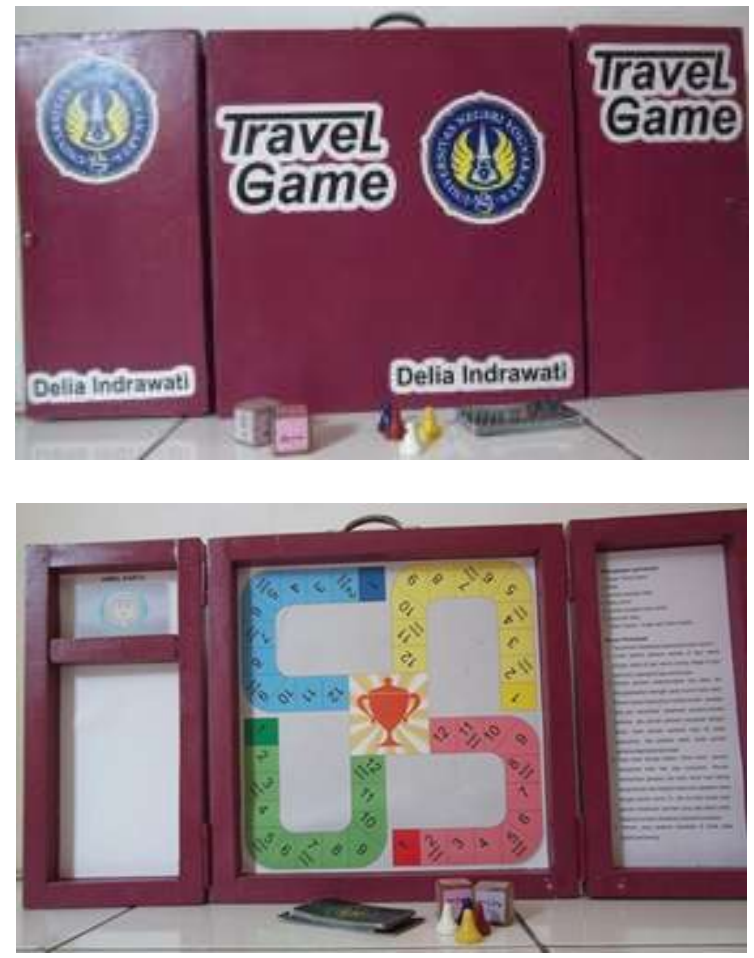

Gambar 12. Produk Akhir Perangkat Media Travel Game

\section{Simpulan dan Saran}

Simpulan

Media travel game yang dikembangkan untuk pembelajaran Matematika kelas V SD layak digunakan. Hal ini karena hasil kelayakan media travel game oleh ahli materi dan media mendapatkan penilaian "baik". Hasil kelayakan media travel game oleh siswa dalam tahap one to one evaluation mendapatkan penilaian "baik", tahap small group evaluation mendapatkan penilaian "baik", dan tahap field evaluation mendapatkan penilaian "baik sekali" dari siswa dan mendapat penilaian "baik" dari hasil observasi guru pada pelaksanaan pembelajaran dengan media travel game. 
Media travel game efektif digunakan untuk pembelajaran matematika kelas V SD materi perkalian dan pembagian bilangan pecahan. Dengan $\mathrm{t}_{\text {hitung }}=-9,764$ maka $\mathrm{H}_{0}$ ditolak, sehingga rata-rata skor pretest dan posttest adalah berbeda secara nyata/pembelajaran efektif.

Keterbatasan

Penelitian pengembangan media travel game untuk pembelajaran matematika memiliki keterbatasan sebagai berikut:

Media travel game yang telah dikembangkan diujicobakan terbatas pada satu sekolah dasar saja. Jika uji coba terbatas dilakukan di beberapa sekolah dasar yang lain, maka dapat diperoleh perangkat pembelajaran yang lebih baik atau layak.

Terbatasnya waktu yang diberikan sekolah untuk melaksanakan uji coba terbatas, sehingga pembelajaran hanya dapat dilakukan selama dua kali pertemuan.

Saran pemanfaatan

Media travel game yang telah dikembangkan diharapkan dapat diterapkan dan digunakan secara maksimal oleh guru matematika untuk bisa meningkatkan keterampilan berhitung siswa SD.

Desiminasi

Media travel game dapat didesiminasikan yaitu: melalui kerja sama dengan dinas pendidikan pemerintah terkait, melalui musyawarah pendidik mata pelajaran (MGMP) matematika, melalui pelatihan tentang media pembelajaran bagi pendidik SD/MI, dan melalui berbagai forum lainnya sehingga media travel game yang dikembangkan ini dapat digunakan oleh seluruh sekolah SD/MI, khususnya untuk pembelajaran matematika kelas $\mathrm{V}$ dalam hal meningkatkan hasil belajar siswa.

Saran

Bagi para peneliti yang mengambil judul yang relevan dengan penelitian ini, diharapkan dapat mengembangkan media travel game lebih lanjut baik dari segi keluasan, kedalaman dan keterkinian materinya sesuai dengan kurikulum yang berlaku sehingga menjadi salah satu sumber belajar yang baik untuk peserta didik.

\section{Daftar Pustaka}

Abdurahman, Mulyono. (2003). Pendidikan bagi anak berkesulitan belajar. Jakarta: Rineka Cipta.

Booker,G., Bond, D., Sparrow,L., \& Swan, P. (2009). Teaching primary mathematic. Frenchs Forest: Pearson Education Australia.

Depdiknas. (2002). Peraturan Menteri Pendidikan Nasional Nomor 22, Tahun 2006, tentang Standar ISI untuk Satuan Pendidikan Dasar dan Menengah.

. (2007). Peraturan Menteri Pendidikan Nasional Nomor 41, Tahun 2007, tentang Standar Proses untuk Satuan Pendidikan Dasar dan Menengah.

Dick,W., Carey, L., \& Carey, J.O. (2005). The systematic design of instruction ( $\left.6{ }^{\mathrm{ed}}\right)$. Boston: Allyn \& Bacon.

Heruman. (2008). Model pembelajaran matematika:di sekolah dasar. Bandung: PT. Remaja Rosdakarya.

Puspendik. (2012). Statistik hasil ujian nasional jenjang smp/mts/terbuka negeri dan swasta. Diakses 5 Februari 2012, dari http://118.98.234.22/sekretariat/hasilun/ index.php/statistik_smp/.

Sadiman, Arief. (2009). Media pendidikan: pengertian, pengembangan dan pemanfaatannya. Jakarta: PT. Raja Grafindo Persada.

Sugar, S. \& Sugar, K.K. (2002). Primary games: experiental learning activities for teaching children $K-8$ ( $\left.1^{\text {st }}\right)$. San Fransisco: Jossey Bas 